\title{
Wpływ silników spalinowych pojazdów trakcyjnych eksploatowanych w kraju na środowisko - próby i badania oraz wytyczne dla redukcji emisji składników szkodliwych
}

\begin{abstract}
Artykuł poświęcony jest zagadnieniom ekologicznej eksploatacji silników spalinowych lokomotyw, lekkich pojazdów szynowych oraz pojazdów specjalnych na krajowych liniach kolejowych. Przedstawiono przyczyny emisji składników szkodliwych oraz limity emisji spalin z pojazdów trakcyjnych wedlug obowiazujacych przepisów i dyrektyw. Ponadto zaprezentowano aparature wraz z metodykami badań i zasadami określania poziomów emisji najważniejszych składników toksycznych oraz przedstawiono wyniki badań prowadzonych na lokomotywach, lekkich i specjalnych pojazdach szynowych. W zakończeniu podano wskazówki dla spetnienia przez silniki spalinowe określonych wymagań w zakresie emisji składników toksycznych.
\end{abstract}

\section{Wstęp}

Na przestrzeni ostatnich kilku lat została sprowadzona do kraju coraz większa liczba spalinowych pojazdów trakcyjnych (w tym lokomotyw, lekkich i specjalnych pojazdów szynowych), których silniki spalinowe nie spełniają wymagań w zakresie limitów emisji składników toksycznych. Spowodowane jest to przede wszystkim liberalizacją rynku kolejowego w kraju i pojawieniem się ponad trzydziestu przewoźników (tzw. operatorów prywatnych) oraz prywatnych firm zajmujących się naprawami i modernizacjami pojazdów trakcyjnych z napędem spalinowym.

Udział pracy spalinowych pojazdów trakcyjnych w warunkach biegu jałowego wynosi 51,6\% całkowitego czasu jej pracy, $33 \%$ czasu pracy odpowiada $10 \%$ znamionowej mocy użytecznej, a pozostałe udziały są znikome. Pojazdy spalinowe wypadają więc bardzo niekorzystnie w ocenie ekologicznej w odniesieniu do pojazdów elektrycznych (rys. 1).

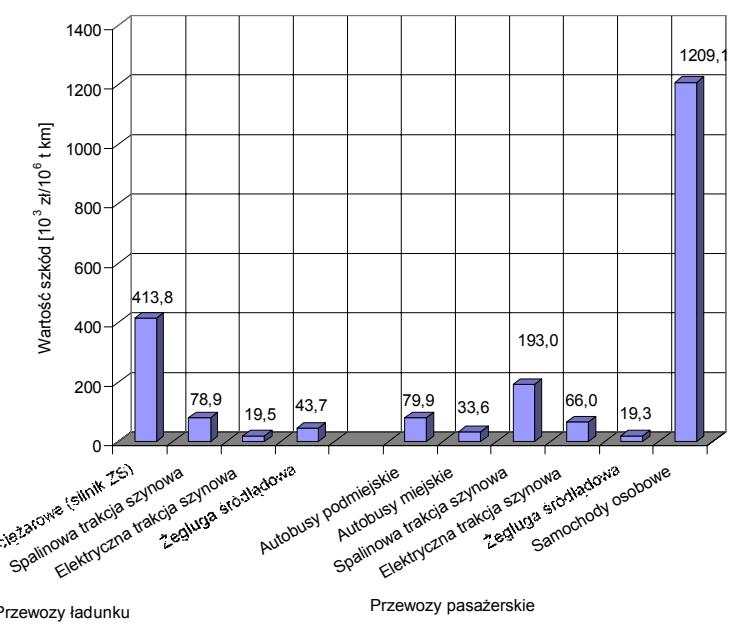

Rys. 1. Porównanie wartości szkód wyrządzanych środowisku naturalnemu przez różne środki transportowe
Wartości szkód wyrządzonych środowisku naturalnemu w Polsce przez pojazdy spalinowe w czasie przewozu ładunków są 4-krotnie większe od szkód wyrządzonych przez pojazdy elektryczne, 1,8 razy większe niż dla żeglugi śródlądowej, jednak są 5krotnie mniejsze od szkód spowodowanych przez samochody ciężarowe $\mathrm{z}$ silnikami o zapłonie samoczynnym. Wartość emisji związków szkodliwych zawartych w spalinach ze źródeł pozadrogowych, do których należą też spalinowe pojazdy szynowe, stanowi znaczący udział $\mathrm{w}$ odniesieniu do pojazdów drogowych.

Każdy $\mathrm{z}$ naprawianych lub remotoryzowanych (związanych $\mathrm{z}$ wymianą silnika spalinowego) pojazdów trakcji szynowej, jeżeli nie posiada udokumentowanych wyników prób i badań silników, zostaje poddany badaniom, m.in. związanym $\mathrm{z}$ określeniem zawartości głównych składników toksycznych spalin. Wynika to z zakresu badań, koniecznych do uzyskania świadectwa dopuszczenia do eksploatacji typu pojazdów kolejowych, opublikowanego w Rozporządzeniu Ministra Infrastruktury z dnia 12.10.2005 r., (Dz.U. Nr 212 poz. 1772).

Ponadto przewiduje się, że każdy spalinowy pojazd trakcyjny podczas naprawy rewizyjnej oraz głównej, będzie poddawany specjalistycznym badaniom silnika spalinowego pod względem emisji składników toksycznych spalin. Z tego względu w IPS „Tabor” Poznań przy udziale Instytutu Silników Spalinowych Politechniki Poznańskiej w ostatnich latach opracowano szczegółowe warunki techniczne dla odbioru spalinowych pojazdów szynowych, w tym autobusów szynowych oraz pojazdów pomocniczych i specjalnych, sprowadzanych z zagranicy i doposażonych w urządzenia i układy gwarantujące $z$ jednej strony bezpieczeństwo ruchu na krajowej sieci kolejo- 
wej, a z drugiej możliwość minimalnego oddziaływania na środowisko naturalne człowieka.

\section{Przyczyny powstawania składników szkodli- wych spalin}

Źródłami substancji zanieczyszczających, emitowanych do atmosfery przez silniki spalinowe sa przede wszystkim:

- układ wylotowy silnika,

- skrzynia korbowa,

- układ zasilania w paliwo.

Zasadniczymi gazowymi toksycznymi składnikami spalin są: tlenek węgla, niespalone węglowodory oraz tlenki azotu. Ponadto, powstającymi głównie w silnikach o zapłonie samoczynnym są również emitowane cząstki stałe (PM - particulate matter). Nie sa to jednak jedyne składniki emitowane $\mathrm{z}$ pojazdu wyposażonego w silnik spalinowy (rys. 2). Emitowane są również pyły, hałas i powstający w wyniku reakcji chemicznych smog. Obecnie głównym problemem dotyczącym emisji jest ograniczenie tlenków azotu oraz cząstek stałych (rys. 3). Jednakże redukcja tych dwóch składników nie przebiega jednocześnie. Ograniczenie jednego $\mathrm{z}$ nich powoduje wzrost emisji drugiego.

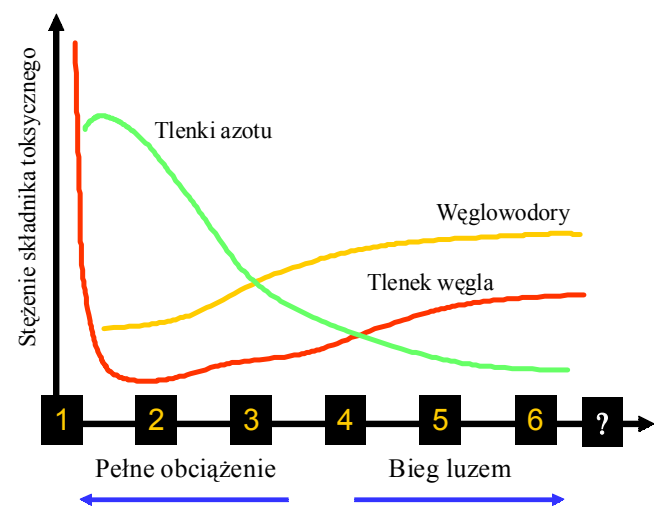

Rys. 2. Powstawanie składników w różnych stanach pracy silnika spalinowego o zapłonie samoczynnym $(\lambda$-współczynnik nadmiaru powietrza)

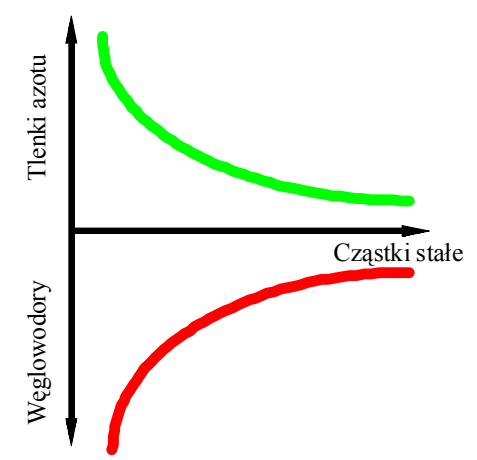

Rys. 3. Współzależności emisji głównych składników toksycznych spalin silników o zapłonie samoczynnym
Węglowodory aromatyczne powodują zwiększenie okresu opóźnienia zapłonu i są odpowiedzialne za spalanie stukowe w silniku. $Z$ tego też względu nie są pożądanymi składnikami oleju napędowego. Również ze względu na ochronę środowiska ich obecność w paliwach jest wysoce niewskazana: podczas ich spalania (szczególnie węglowodorów wielopierścieniowych) tworzą się produkty o właściwościach kancerogennych (rakotwórczych), które są wprowadzane do atmosfery wraz ze spalinami.

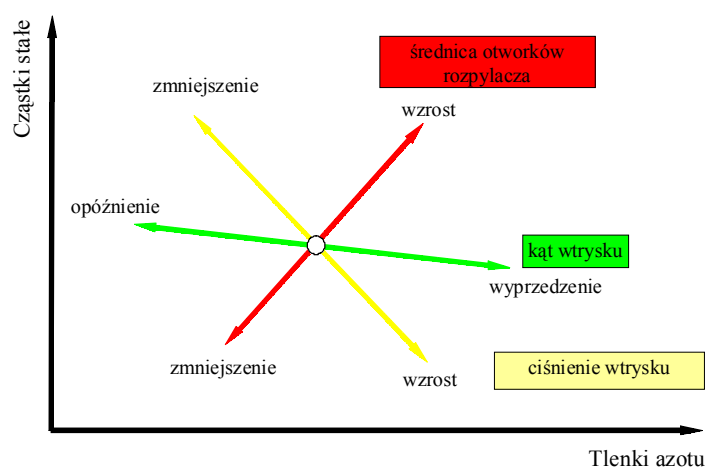

Rys. 4. Główne przyczyny zmian emisji cząstek stałych i tlenków azotu w silniku spalinowym o zapłonie samoczynnym

Zawartość siarki jest jednym z parametrów oleju napędowego, który w największym stopniu wpływa na poziom emisji cząstek stałych. Siarka z jednej strony intensyfikuje tworzenie cząstek stałych $\mathrm{w}$ procesie roboczym silnika, z drugiej obniża skuteczność układów oczyszczania spalin.

\section{Przepisy regulujące próby i badania silników spalinowych pojazdów szynowych}

W ostatnich latach w Europie zwraca się coraz większą uwagę na ochronę środowiska naturalnego człowieka. Dotyczy to nie tylko emisji substancji szkodliwych przez przemysł, w tym huty, elektrownie, zakłady ciepłownicze, ale również emisji składników toksycznych do atmosfery przez środki transportu, w tym transportu szynowego.

Obecnie w Europie obowiązują przepisy UIC [12, 18] oraz Dyrektywa 2004/26 [14] (nowelizacja dyrektywy 97/68) Komisji Europejskiej, regulujące wymagania dla silników spalinowych pojazdów trakcyjnych w zakresie dopuszczalnych składników toksycznych zawartych $\mathrm{w}$ spalinach emitowanych do atmosfery. Przepisy UIC nie maja jednak umocowania prawnego w świetle prawa międzynarodowego, a są tylko zobowiązaniami wszystkich kolei skupionych w Międzynarodowym Związku Kolejowym [11].

Obecnie, w związku z pojawieniem się na rynku europejskim (unijnym) wielu prywatnych firm realizujących prace przewozowe (zwłaszcza towarów), została wydana Dyrektywa 2004/26 mająca moc prawa unijnego, w której określono szczegółowo wymagania w zakresie dopuszczalnych wartości emisji 
Parametry cykli badawczych pojazdów szynowych wykonywanych według testu PN-EN ISO $8178[16,17]$

Tabela 1

\begin{tabular}{|l|ccccc|ccccc|c|}
\hline Faza & $\mathbf{1}$ & $\mathbf{2}$ & $\mathbf{3}$ & $\mathbf{4}$ & $\mathbf{5}$ & $\mathbf{6}$ & $\mathbf{7}$ & $\mathbf{8}$ & $\mathbf{9}$ & $\mathbf{1 0}$ & $\mathbf{1 1}$ \\
\hline Mo [\%] & 100 & 75 & 50 & 25 & 10 & 100 & 75 & 50 & 25 & 10 & 0 \\
Prędkość & \multicolumn{7}{|c|}{ Maksymalna prędkość } & & & \multicolumn{2}{l}{$\begin{array}{l}\text { Średnia prędkość } \\
\text { C1 }\end{array}$} \\
\hline & 0,15 & 0,15 & 0,15 & - & 0,10 & 0,10 & 0,10 & 0,10 & - & - & 0,15 \\
F & 0,25 & - & - & - & - & - & - & 0,15 & - & - & 0,60 \\
\hline
\end{tabular}

gdzie: Mo - moment obrotowy silnika w \%, C1 i F - cykle badawcze silników pojazdów szynowych

składników toksycznych spalin. Wymagania te dotyczą zarówno pojazdów drogowych jak i szynowych z różnymi rodzajami silników spalinowych i są bardzo ważne również $\mathrm{w}$ przypadku zastosowania silników samochodowych do spalinowych pojazdów trakcyjnych (np. w lekkich pojazdach, autobusach szynowych, pojazdach pomocniczych i specjalnych).

Badania silników spalinowych pojazdów trakcyjnych prowadzone są najczęściej według testu PN-EN ISO 8178 cykl F oraz C1 (tabela 1).

Poniżej przedstawiono skrótowe informacje o poszczególnych testach oraz dopuszczalne limity składników toksycznych ujętych w poszczególnych przepisach i normach:

- test badawczy według PN-EN ISO 8178 cykl $\mathrm{F}$ [12] uwzględnia trzy punkty pomiarowe. Dopuszczalne limity emisji według obowiązujących kart UIC [18] przedstawiono na rysunku 5.
- test badawczy według PN-EN ISO 8178, cykl C1 dla silników zabudowywanych przede wszystkim w lekkich pojazdach szynowych, np. w autobusach szynowych i pojazdach specjalnych.

Dopuszczalne limity emisji dla poszczególnych etapów wprowadzania według Dyrektywy Komisji Europejskiej przedstawiono w tabeli $2[13,14]$.

Ponadto dla pojazdów szynowych, w których zostaną zastosowane silniki samochodowe $\mathrm{z}$ zapłonem samoczynnym, zalecane są badania według następujących testów $[13,14]$ :

- ESC - stacjonarny test europejski (tab. 3)

- ELR - obciążeniowy test europejski

- ETC - europejski test niestacjonarny.

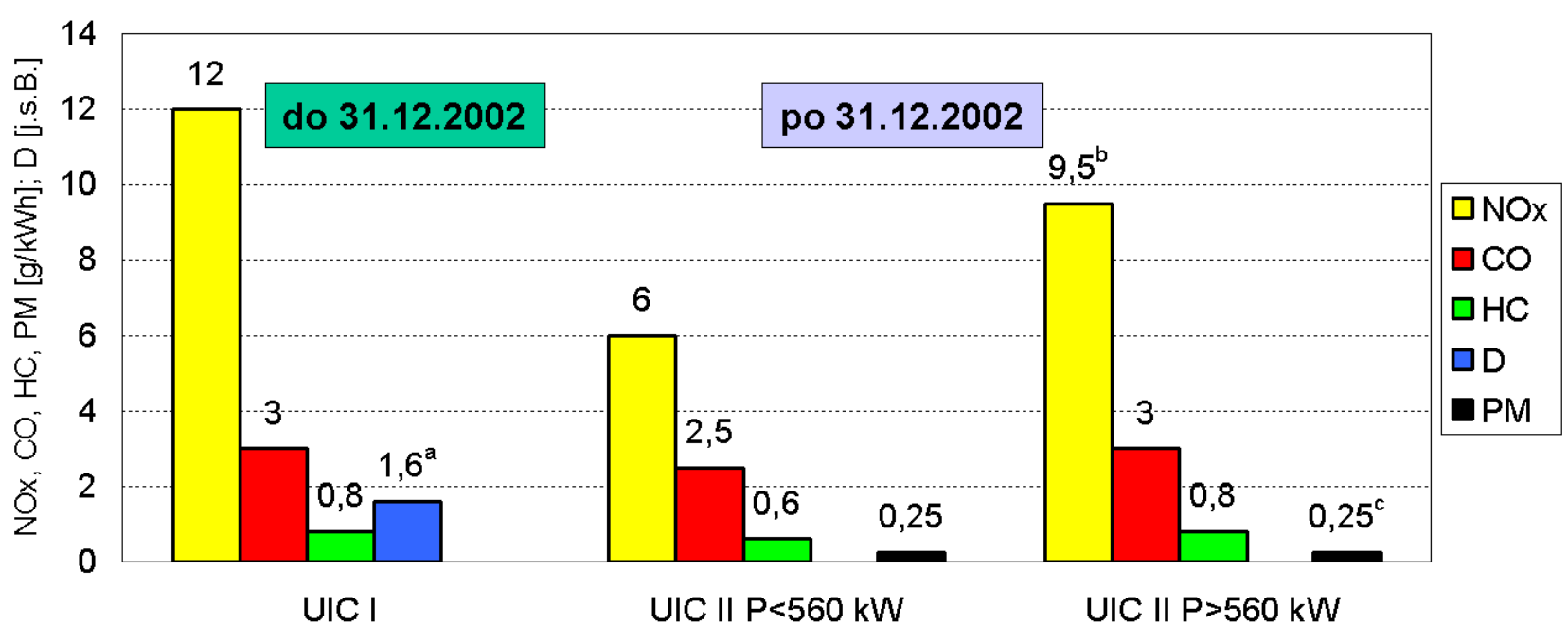

Rys. 5. Limity emisji spalin wg kart UIC 623-2 i UIC 624; a - przy wydatku powietrza powyżej 1,0 kg/s wartość zadymienia D wynosi 2,5 j.s.B.; b - obowiązuje dla prędkości $\mathrm{n}>1000 \mathrm{obr} / \mathrm{min}$, dla $\mathrm{n}<1000 \mathrm{obr} / \mathrm{min}$ limit wynosi $9,9 \mathrm{~g} / \mathrm{kW} \cdot \mathrm{h} ; \mathrm{c}-\mathrm{dla}$ silników o mocy nominalnej powyżej $2200 \mathrm{~kW}$ emisja PM była wyjątkowo dopuszczona do 31.12 .2004 r. na poziomie 0,5 $\mathrm{g} / \mathrm{kW} \cdot \mathrm{h}$ lecz zaleca się zachowywać wartość graniczną $0,25 \mathrm{~g} / \mathrm{kW} \cdot \mathrm{h}$, od $1.01 .2005 \mathrm{r}$. wartość graniczna $0,25 \mathrm{~g} / \mathrm{kW} \cdot \mathrm{h}$ obowiązuje dla wszystkich silników [4] 
Limity emisji spalin wg Dyrektywy 2004/26 (nowelizacja dyrektywy 97/68) Komisji Europejskiej

Tabela 2

\begin{tabular}{|c|c|c|c|c|c|c|c|c|}
\hline \multicolumn{2}{|c|}{$\begin{array}{lr}\begin{array}{l}\text { Data } \\
\text { Wprowadzenia } \\
\text { (obowiązywania) }\end{array} & \begin{array}{r}\text { Emisja } \\
{[\mathrm{g} / \mathrm{kW} \cdot \mathrm{h}]}\end{array} \\
\end{array}$} & \multirow{2}{*}{$\begin{array}{c}\text { Typ pojazdu } \\
\text { trakcyjnego } \\
\text { i jego moc } \\
\text { W kW } \\
\text { Wagon motorowy } \\
\text { P > 130 }\end{array}$} & \multirow{2}{*}{\begin{tabular}{|l|} 
Co \\
3,5
\end{tabular}} & \multirow{2}{*}{$\begin{array}{c}\mathrm{HC} \\
-\end{array}$} & \multirow{2}{*}{$\begin{array}{c}\text { HC+NOx } \\
4\end{array}$} & \multirow{2}{*}{$\begin{array}{c}\text { NOx } \\
-\end{array}$} & \multirow{2}{*}{$\begin{array}{l}\mathrm{PM} \\
0,2\end{array}$} & \multirow{2}{*}{$\begin{array}{l}\text { Test } \\
\text { C1 }\end{array}$} \\
\hline \multirow{4}{*}{ IIIA } & $\begin{array}{c}\text { RCA } \\
\left.01.07 .05 / 01.01 .06^{*}\right)\end{array}$ & & & & & & & \\
\hline & $\begin{array}{c}\text { RL A } \\
\left.01.01 .06 / 01.01 .06^{*}\right)\end{array}$ & $\begin{array}{l}\text { Lokomotywa } \\
130<P<560\end{array}$ & 3,5 & - & 4 & - & 0,2 & $\mathbf{F}$ \\
\hline & $\begin{array}{c}\text { RHA } \\
\left.01.01 .08 / 01.01 .09^{*}\right)\end{array}$ & $\begin{array}{l}\text { Lokomotywa } \\
\text { P > 560 }\end{array}$ & 3,5 & 0,5 & - & 6 & 0,2 & $\mathbf{F}$ \\
\hline & $\begin{array}{c}\text { RH A } \\
\left.01.01 .08 / 01.01 .09^{*}\right)\end{array}$ & $\begin{array}{l}\text { Lokomotywa } \\
\qquad \begin{array}{l}P>2000 \\
\text { i } V_{c}>5 \mathrm{dm}^{3}\end{array}\end{array}$ & 3,5 & 0,4 & - & 7,4 & 0,2 & $\mathbf{F}$ \\
\hline \multirow{2}{*}{ IIIB } & $\begin{array}{c}\text { RC B } \\
\left.01.01 .11 / 01.01 .12^{*}\right)\end{array}$ & $\begin{array}{l}\text { Wagon motorowy } \\
\quad P>130\end{array}$ & 3,5 & 0,19 & - & 2 & 0,025 & C1 \\
\hline & $\begin{array}{c}\text { R B } \\
\left.01.01 .11 / 01.01 .12^{\star}\right)\end{array}$ & $\begin{array}{l}\text { Lokomotywa } \\
P>130\end{array}$ & 3,5 & - & 4 & - & 0,025 & C1 \\
\hline \multicolumn{9}{|c|}{ * Data dla procedur dopuszczenia / Data dla eksploatacji } \\
\hline $\begin{array}{l}\mathrm{RC} \\
\mathrm{A}-\end{array}$ & lowe & $\begin{array}{l}\mathrm{R} \text { - zastosowania szy } \\
\mathrm{RH} \text { - lokomotywy du }\end{array}$ & & & $\begin{array}{l}\mathrm{RL}-\mathrm{lo} \\
\mathrm{B}-\mathrm{UIC}\end{array}$ & & $\mathrm{j}$ & \\
\hline
\end{tabular}

Limity emisji spalin wg Dyrektyw 1999/96/EC i 2001/27/EC Parlamentu Europejskiego dla spalinowych silników samochodowych z zapłonem samoczynnym

Tabela 3

\begin{tabular}{|c|c|c|c|c|c|c|c|}
\hline \multicolumn{2}{|c|}{$\begin{array}{l}\text { Data } \\
\text { wprowadzenia } \\
\text { (obowiązywania) }\end{array}$} & \multirow{2}{*}{$\begin{array}{c}\begin{array}{c}\text { Rodzaj } \\
\text { testu }\end{array} \\
\text { ECE R49 }\end{array}$} & \multirow{2}{*}{$\begin{array}{l}\text { CO } \\
4,5\end{array}$} & \multirow{2}{*}{$\begin{array}{l}\mathrm{HC} \\
1,1\end{array}$} & \multirow{2}{*}{$\begin{array}{c}\mathrm{NO}_{\mathrm{x}} \\
8\end{array}$} & \multirow{2}{*}{$\begin{array}{c}\text { PM } \\
0,612\end{array}$} & \multirow{2}{*}{$\begin{array}{c}\begin{array}{c}\text { Zadymienie } \\
{\left[\mathbf{k}^{-1}\right]}\end{array} \\
\text { - }\end{array}$} \\
\hline Euro I & 01.01.1992 & & & & & & \\
\hline \multirow{2}{*}{ Euro II } & 01.10 .1996 & \multirow{2}{*}{ ECE R49 } & 4 & 1,1 & 7 & 0,25 & - \\
\hline & 01.10 .1998 & & 4 & 1,1 & 7 & 0,15 & - \\
\hline \multirow{2}{*}{ Euro III } & 01.01.1999 & \multirow{4}{*}{ ESC i ELR } & 1,5 & 0,25 & 2 & 0,02 & 0,15 \\
\hline & 01.10 .2000 & & 2,1 & 0,66 & 5 & 0,10 & 0,8 \\
\hline Euro IV & 01.10 .2005 & & 1,5 & 0,46 & 3,5 & 0,02 & 0,5 \\
\hline Euro V & 01.10 .2008 & & 1,5 & 0,46 & 2 & 0,02 & 0,5 \\
\hline
\end{tabular}

4. Zestawienie badanych pojazdów trakcyjnych i

\section{ich charakterystyka}

Badania przeprowadzono w większości na lokomotywach i lekkich pojazdach szynowych (autobusy szynowe, pojazdy pomocnicze i pojazdy specjalne) sprowadzonych z zagranicy i poddanych naprawom głównym lub remotoryzacjom w zakładach naprawczych i zakładach produkujących tabor kolejowy.

Zestawienie spalinowych pojazdów szynowych przedstawiono w tabeli 4 , natomiast pełne parametry badanych silników spalinowych podano w tabeli 5 .

Pojazdy szynowe poddane badaniom emisji składników toksycznych spalin

Tabela 4

\begin{tabular}{|l|l|c|c|c|}
\hline $\mathbf{N r}$ & \multicolumn{1}{|c|}{ Opis } & Typ silnika & Moc silnika & Widok pojazdu \\
\hline 1 & $\begin{array}{l}\text { Lokomotywa manewrowa 6D } \\
\text { (SM42) }\end{array}$ & $\mathrm{a} 8 \mathrm{C} 22$ & $588 \mathrm{~kW}$ & \\
\hline 2 & $\begin{array}{l}\text { Lokomotywa ST44 doposażona } \\
\text { przez ZNTK Poznań }\end{array}$ & $14 \mathrm{D} 40$ & $1470 \mathrm{~kW}$ & \\
\hline
\end{tabular}




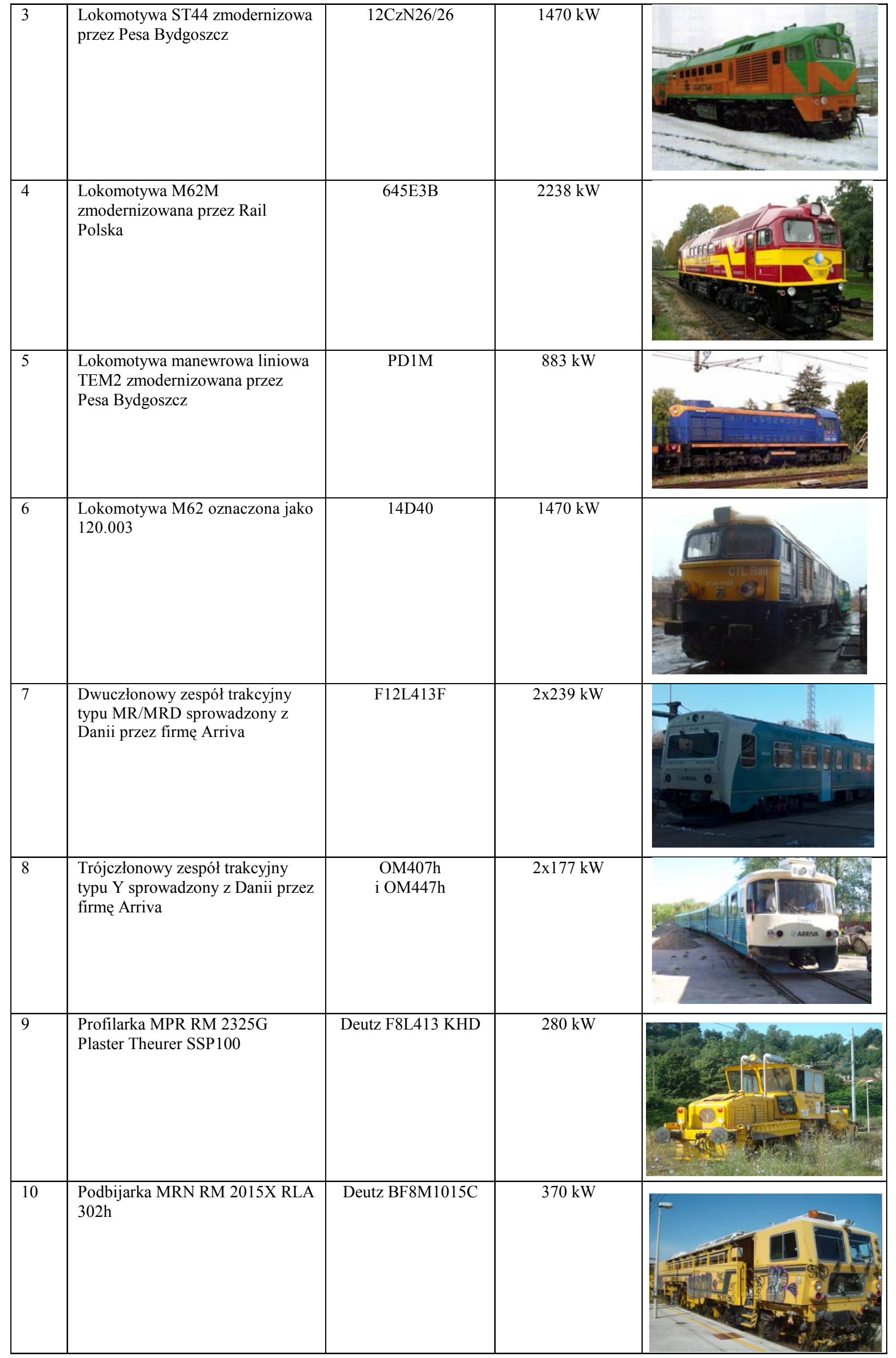




\begin{tabular}{|l|l|l|l|l|}
\hline 11 & $\begin{array}{l}\text { Maszyna do poziomowania toru } \\
\text { MST RM 2008N }\end{array}$ & Deutz BF12L513C & $348 \mathrm{~kW}$ & \\
\hline 12 & Czyszczarka MRJ RM 2307D & Deutz BF12L513C & $333 \mathrm{~kW}$ & \\
\hline 13 & $\begin{array}{l}\text { Maszyna do zgrzewania szyn } \\
\text { MSL RM 2040P }\end{array}$ & Deutz BF12L513C & $348 \mathrm{~kW}$ & \\
\hline
\end{tabular}

5. Wyniki pomiarów emisji składników toksycznych silników lokomotyw spalinowych

Pomiary emisji składników toksycznych spalin prowadzono w latach 2006-2008. W przypadkach uzyskiwania wyników odbiegających wyraźnie od limitów (wartości dopuszczalnych) pomiary, po wymianie zużytych elementów (np. wtryskiwaczy) oraz przeprowadzeniu dodatkowych regulacji w układzie paliwowym, były powtarzane.
Poniżej podano uzyskane wyniki z badań silników poszczególnych pojazdów prowadzonych według PNEN ISO 8178-1 dla cyklu F wraz z odniesieniami do obowiązujących przepisów i norm [10, 12, 15-19]: badania lokomotyw spalinowych - rys. 6 , badania lekkich pojazdów szynowych - rys. 7 oraz badania specjalnych pojazdów szynowych - rys. 8 . Pełne zestawienie wyników zaprezentowano w tabeli 6 .

Parametry techniczne badanych silników spalinowych

Tabela 5

\begin{tabular}{|c|c|c|c|c|c|c|c|c|}
\hline \multirow[b]{2}{*}{ L.p. } & \multirow{2}{*}{$\begin{array}{c}\text { Typ/seria } \\
\text { badanej } \\
\text { lokomotywy } \\
\text { spalinowej }\end{array}$} & \multirow{2}{*}{$\begin{array}{c}\text { Typ badanego } \\
\text { silnika } \\
\text { spalinowego }\end{array}$} & \multirow{2}{*}{$\begin{array}{c}\text { Moc } \\
\text { silnika } \\
\text { spalinowego } \\
{[\mathrm{kW}]} \\
\end{array}$} & \multirow{2}{*}{$\begin{array}{c}\text { Liczba/uklad } \\
\text { cylindrów } \\
\mathbf{R} \text { - rzędowy } \\
\text { V-widlasty }\end{array}$} & \multirow{2}{*}{$\begin{array}{c}\text { Prędkość } \\
\text { obrotowa } \\
\mathbf{N}_{\mathrm{e}-\max } \\
{[0 \mathrm{br} / \mathrm{min}]}\end{array}$} & \multirow{2}{*}{$\begin{array}{c}\begin{array}{c}\text { Objętość } \\
\text { skokowa } \\
\text { silnika }\end{array} \\
{\left[\mathrm{dm}^{3}\right]} \\
\end{array}$} & \multicolumn{2}{|c|}{$\begin{array}{c}\text { Zużycie jednostkowe } \\
{[\mathrm{g} / \mathrm{kW} \cdot \mathbf{h}]}\end{array}$} \\
\hline & & & & & & & $\begin{array}{c}\text { oleju } \\
\text { napędowego } \\
\text { (paliwa) }\end{array}$ & $\begin{array}{c}\begin{array}{c}\text { oleju } \\
\text { smarnego }\end{array} \\
\end{array}$ \\
\hline 1. & \begin{tabular}{|l} 
Lokomotywa manewrowa 6D (SM42) \\
\end{tabular} & $\mathrm{a} 8 \mathrm{C} 22$ & 588 & $8 / \mathrm{V}\left(50^{\circ}\right)$ & 1000 & 82,1 & 224,4 & 4,8 \\
\hline 2. & $\begin{array}{l}\text { Lokomotywa ST44 doposażona przez } \\
\text { ZNTK Poznań }\end{array}$ & $14 \mathrm{D} 40$ & 1470 & $12 / \mathrm{V}\left(45^{\circ}\right)$ & 750 & 150,6 & 228 & 2,7 \\
\hline 3. & $\begin{array}{l}\text { Lokomotywa ST44 zmodern. przez Pesa } \\
\text { Bydgoszcz }\end{array}$ & $12 \mathrm{CzN} 26 / 26$ & 1470 & $12 / \mathrm{V}\left(60^{\circ}\right)$ & 750 & 150,6 & 202,5 & 0,8 \\
\hline 4. & $\begin{array}{l}\text { Lokomotywa M62M modern. przez Rail } \\
\text { Polska }\end{array}$ & $645 \mathrm{E} 3 \mathrm{~B}$ & 2238 & $16 / \mathrm{V}\left(45^{\circ}\right)$ & 893 & 105,7 & - & - \\
\hline 5. & $\begin{array}{l}\text { Lokomotywa manewrowa liniowa TEM2 } \\
\text { zmodern. przez Pesa Bydgoszcz }\end{array}$ & PD1M & 883 & $6 / \mathrm{R}$ & 750 & 158,7 & 224 & 2,6 \\
\hline 6. & $\begin{array}{l}\text { Lokomotywa M62 oznaczona jako } \\
120.002\end{array}$ & $14 \mathrm{D} 40$ & 1470 & $12 / \mathrm{V}\left(45^{\circ}\right)$ & 750 & 150,6 & 228 & 2,7 \\
\hline 7. & $\begin{array}{l}\text { Dwuczłonowy zespół trakcyjny typu } \\
\text { MR/MRD }\end{array}$ & F12L413F & $2 \times 239$ & $12 / \mathrm{V}\left(90^{\circ}\right)$ & 2160 & 19,144 & 216 & - \\
\hline 8. & Trójczłonowy zespół trakcyjny typu Y & $\begin{array}{l}\text { OM407h } \\
\text { OM447h }\end{array}$ & $2 \times 177$ & $6 / \mathrm{R}$ & 2100 & 11,967 & 232 & - \\
\hline 9 & $\begin{array}{l}\text { Profilarka MPR RM 2325G Plaster Theu- } \\
\text { rer SSP100 }\end{array}$ & $\begin{array}{c}\text { Deutz } \\
\text { F8L413 KHD } \\
\end{array}$ & 280 & $8 / \mathrm{R}$ & 2500 & 9,57 & 216 & - \\
\hline 10 & Podbijarka MRN RM 2015X RLA 302h & $\begin{array}{c}\text { Deutz } \\
\text { BF8M1015C } \\
\end{array}$ & 370 & $8 / \mathrm{R}$ & 2100 & 15,874 & 189 & - \\
\hline 11 & $\begin{array}{l}\text { Maszyna do poziomowania toru MST RM } \\
2008 \mathrm{~N}\end{array}$ & $\begin{array}{c}\text { Deutz } \\
\text { BF12L513C }\end{array}$ & 348 & $12 / \mathrm{V}$ & 2300 & 19,144 & 205 & - \\
\hline 12 & Czyszczarka MRJ RM 2307D & $\begin{array}{c}\text { Deutz } \\
\text { BF12L513C }\end{array}$ & 333 & $12 / \mathrm{V}$ & 2300 & 19,144 & 212 & - \\
\hline 13 & $\begin{array}{l}\text { Maszyna do zgrzewania szyn MSL RM } \\
\text { 2040P }\end{array}$ & $\begin{array}{c}\text { Deutz } \\
\text { BF12L513C }\end{array}$ & 348 & $12 / \mathrm{V}$ & 2300 & 19,144 & 205 & - \\
\hline
\end{tabular}




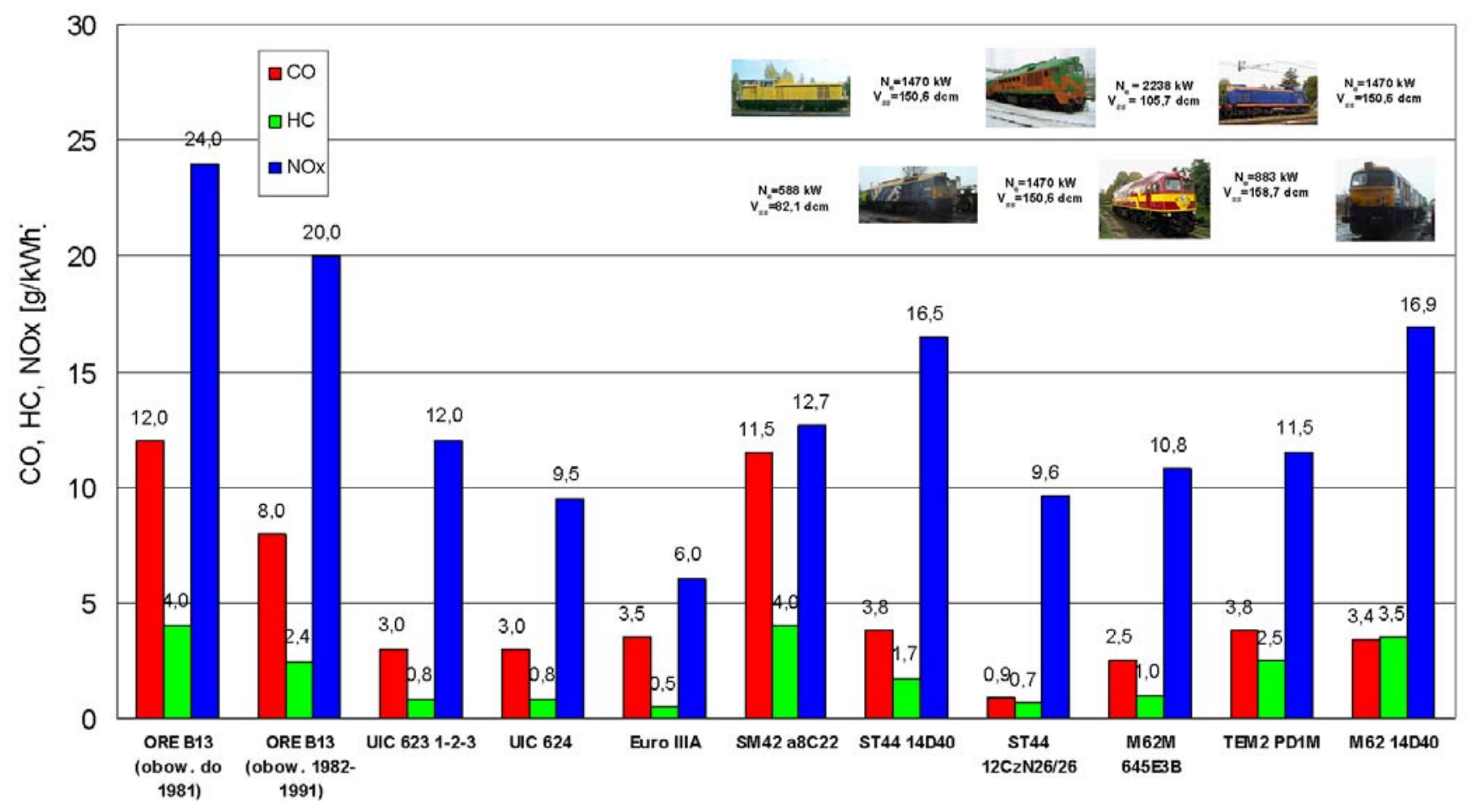

Rys. 6. Wyniki badań składników spalin emitowanych przez lokomotywy spalinowe

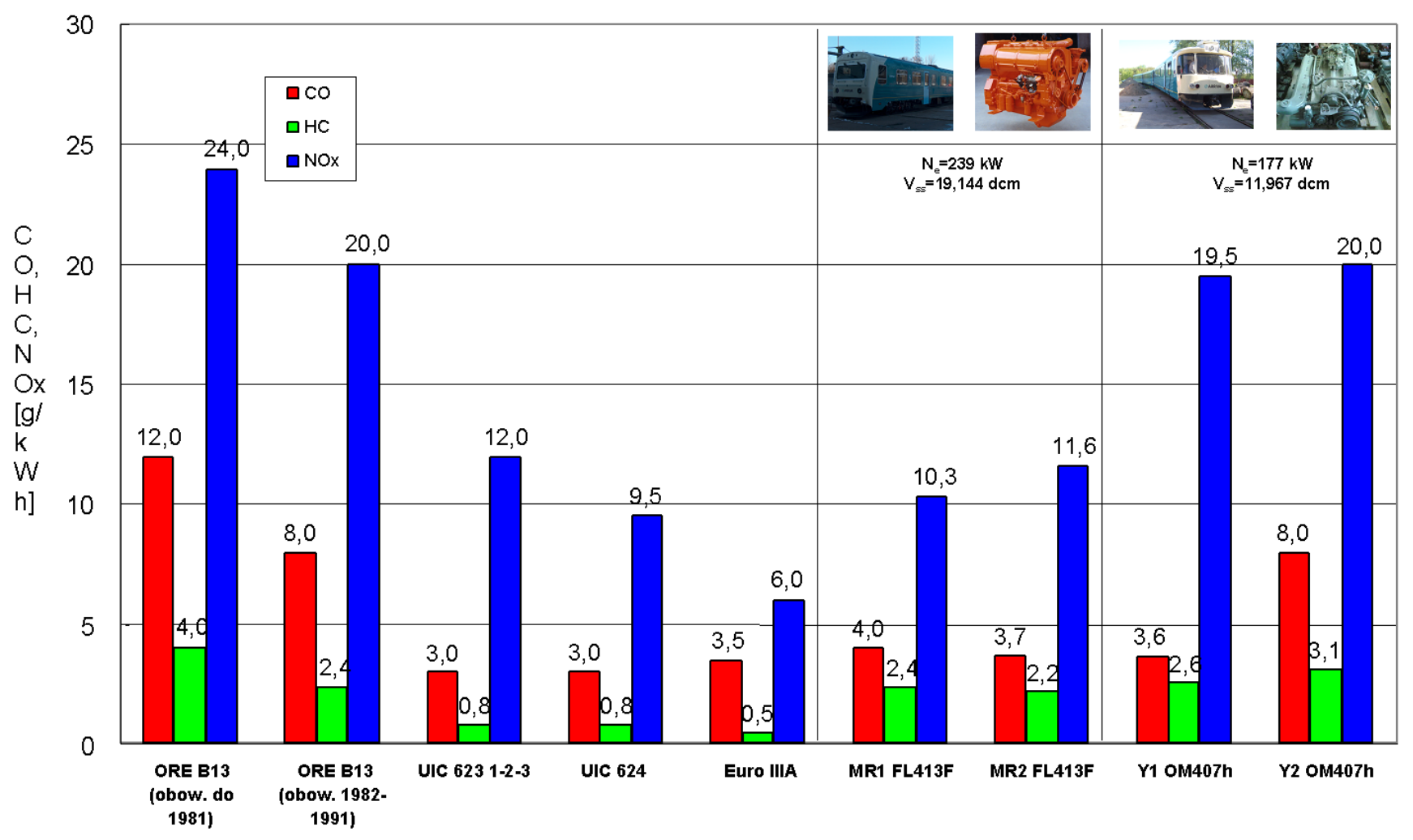

Rys. 7. Wyniki badań składników spalin emitowanych przez lekkie pojazdy szynowe 


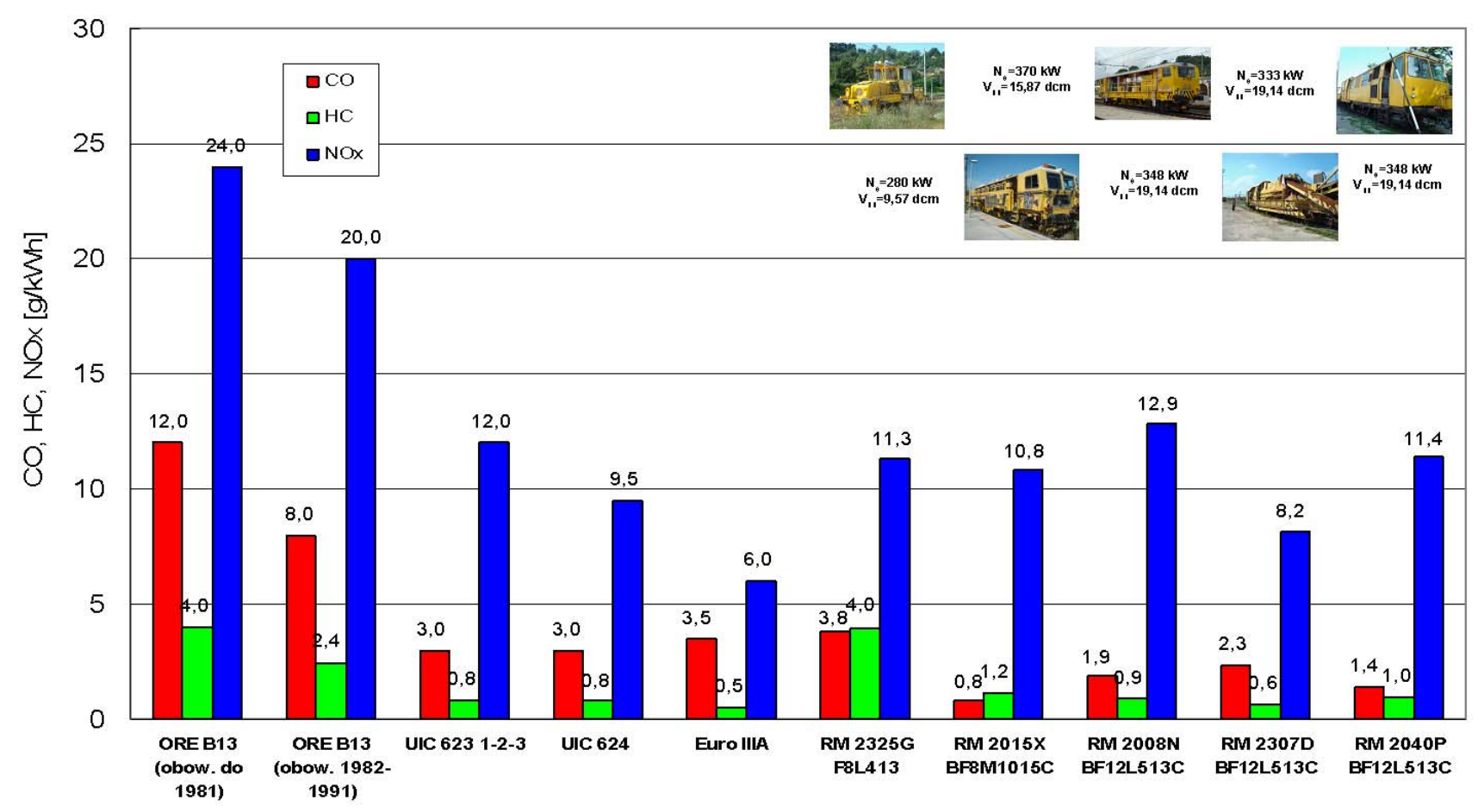

Rys. 8. Wyniki badań składników spalin emitowanych przez specjalne pojazdy szynowe

Zestawienie wyników badań emisji składników toksycznych przez silniki spalinowe wg PN-EN ISO 8178-1 dla cyklu F

Tabela 6

\begin{tabular}{|c|c|c|c|c|c|c|}
\hline Lp. & $\begin{array}{c}\text { Typ/seria } \\
\text { badanego pojazdu spalinowego }\end{array}$ & $\begin{array}{c}\text { Typ badanego } \\
\text { silnika spalino- } \\
\text { wego } \\
\end{array}$ & $\begin{array}{l}\text { Miejsce prowadze- } \\
\text { nia badań }\end{array}$ & $\mathrm{CO}$ & $\mathrm{HC}$ & NOx \\
\hline 1. & Lokomotywa manewrowa 6D (SM42) & a8C22 & ZNTK Poznań & 11,50 & 3,98 & 12,73 \\
\hline 2. & $\begin{array}{l}\text { Lokomotywa ST44 doposażona przez ZNTK } \\
\text { Poznań }\end{array}$ & $14 \mathrm{D} 40$ & ZNTK Poznań & 3,80 & 1,70 & 16,50 \\
\hline 3. & $\begin{array}{l}\text { Lokomotywa ST44 zmodern. przez Pesa } \\
\text { Bydgoszcz }\end{array}$ & $12 \mathrm{CzN} 26 / 26$ & Pesa Bydgoszcz & 0,94 & 0,73 & 9,60 \\
\hline 4. & $\begin{array}{l}\text { Lokomotywa EM62 modern. przez Rail } \\
\text { Polska }\end{array}$ & 645E3B & $\begin{array}{l}\text { Rail Polska, Włosie- } \\
\text { nica }\end{array}$ & 2,50 & 1,03 & 10,77 \\
\hline 5. & $\begin{array}{l}\text { Lokomotywa manewrowa liniowa TEM2 } \\
\text { zmodern. przez Pesa Bydgoszcz }\end{array}$ & PD1M & Pesa Bydgoszcz & 3,83 & 2,45 & 11,51 \\
\hline 6. & Lokomotywa M62 oznaczona jako 120.002 & $14 \mathrm{D} 40$ & ZNTK Poznań & 3,38 & 3,53 & 16,88 \\
\hline $7 \mathrm{a}$. & $\begin{array}{l}\text { Dwuczłonowy zespół trakcyjny typu MR - } 1 \\
\text { silnik }\end{array}$ & F12L413F & IPS Pozanń & 4,04 & 2,37 & 10,30 \\
\hline $7 \mathrm{~b}$. & $\begin{array}{l}\text { Dwuczłonowy zespół trakcyjny typu MRD - } \\
2 \text { silnik }\end{array}$ & F12L413F & IPS Pozanń & 3,69 & 2,24 & 11,60 \\
\hline $8 \mathrm{a}$. & $\begin{array}{l}\text { Trójczłonowy zespół trakcyjny typu Y }-1 \\
\text { silnik }\end{array}$ & OM407h & IPS Poznań & 3,61 & 2,56 & 19,51 \\
\hline $8 \mathrm{~b}$. & $\begin{array}{l}\text { Trójczłonowy zespół trakcyjny typu Y }-2 \\
\text { silnik }\end{array}$ & OM447h & IPS Poznań & 7,95 & 3,05 & 19,99 \\
\hline 9 & $\begin{array}{l}\text { Profilarka MPR RM 2325G Plaster Theurer } \\
\text { SSP100 }\end{array}$ & $\begin{array}{c}\text { Deutz } \\
\text { F8L413 KHD } \\
\end{array}$ & $\begin{array}{l}\text { Manopello/ } \\
\text { Włochy }\end{array}$ & 3,77 & 3,95 & 11,33 \\
\hline 10 & Podbijarka MRN RM 2015X RLA 302h & $\begin{array}{c}\text { Deutz } \\
\text { BF8M1015C }\end{array}$ & $\begin{array}{l}\text { Manopello/ } \\
\text { Włochy }\end{array}$ & 0,83 & 1,16 & 10,83 \\
\hline 11 & $\begin{array}{l}\text { Maszyna do poziomowania toru MST RM } \\
2008 \mathrm{~N}\end{array}$ & $\begin{array}{c}\text { Deutz } \\
\text { BF12L513C }\end{array}$ & $\begin{array}{l}\text { Varano/ } \\
\text { Włochy }\end{array}$ & 1,87 & 0,91 & 12,86 \\
\hline 12 & Czyszczarka MRJ RM 2307D & $\begin{array}{c}\text { Deutz } \\
\text { BF12L513C }\end{array}$ & $\begin{array}{l}\text { Fano/ } \\
\text { Włochy }\end{array}$ & 2,32 & 0,63 & 8,17 \\
\hline 13 & $\begin{array}{l}\text { Maszyna do zgrzewania szyn MSL RM } \\
2040 \mathrm{P}\end{array}$ & $\begin{array}{c}\text { Deutz } \\
\text { BF12L513C }\end{array}$ & $\begin{array}{c}\text { Priverno/ } \\
\text { Włochy }\end{array}$ & 1,42 & 0,95 & 11,41 \\
\hline
\end{tabular}


Po wykonanych badaniach i przeprowadzonych analizach należy stwierdzić, że przy prawidłowych regulacjach, wymianach zużytych elementow oraz części, silniki spełniają w zasadzie dopuszczalne wartości dla norm i przepisów obowiązujących w latach, w których je wyprodukowano i wdrażano do eksploatacji. Zaznaczyć należy również, że na tle nowoczesnych silników np. $12 \mathrm{CzN} 26 / 26$ pozostałe silniki, zwłaszcza dwusuwowe, prezentują się $\mathrm{w}$ miarę dobrze.

Biorąc ponadto pod uwagę to, że udział poszczególnych spalinowych pojazdów trakcyjnych w pracach przewozowych i pomocniczych w kraju jest wielokrotnie niższy od udziału transportu drogowego (zwłaszcza autobusowego i ciężarowego) emitowane przez nie składniki toksyczne do atmosfery są niewielkie więc oddziaływanie na środowisko naturalne może być niezauważalne.

Nie mniej jednak należałoby po każdej naprawie dokonywać okresowych sprawdzeń emisji spalin, zwłaszcza w odniesieniu do pojazdów starszych wiekiem.

\section{Podsumowanie}

Wykonane badania i przeprowadzone analizy potwierdzają że dla wszystkich sprowadzanych spalinowych pojazdów trakcyjnych, nie spełniających wymagań w zakresie emisji składników toksycznych spalin, należy dążyć docelowo do wymiany przestarzałych silników (zwłaszcza dwusuwowych) na silniki nowocześniejsze.

W ramach doraźnych rozwiązań, zmniejszających szkodliwe oddziaływanie na środowisko naturalne przez silniki starszej generacji, poza wymienionymi już w pracy [2], należałoby zainstalować:

- pozasilnikowe układy oczyszczania spalin w postaci utleniających reaktorów katalitycznych dla zmniejszenia emisji tlenku węgla i węglowodorów, np. dwu- lub jednowejściowe płaskie i okragłe katalizatory z tłumikami lub bez

- filtry cząstek stałych

- filtry sadzy (zamienne $\mathrm{z}$ filtrami cząstek stałych).

Możliwości zmniejszenia emisji dla poszczególnych składników szkodliwych można ująć w następujący sposób:

- dla emisji tlenków azotu:

- opóźnienie kąta początku wtrysku paliwa

- właściwe ciśnienie początku wtrysku paliwa

- regulacja ciśnienia doładowania

- dla emisji tlenku węgla:

- wymiana i regulacja wtryskiwaczy

- utrzymanie współczynnika nadmiaru
- powietrza (przez ustawienie właściwego ciśnienia doładowania) na prawidłowym poziomie $w$ warunkach mocy maksymalnej

- dla emisji węglowodorów:

- wymiana lub regulacja rozpylaczy wtryskiwaczy

- konieczność sprawdzenia ciśnienia sprężania (indykowanie silnika) w celu ewentualnej wymiany zestawów tłokpierścienie

- dla emisji cząstek stałych:

- prawidłową regulację układu recyrkulacji spalin

- wyposażenie silnika w układy oczyszczania spalin.

Główne możliwości redukcji emisji składników szkodliwych spalin w silniku to:

- w zakresie spalania:

- zastosowanie niskociśnieniowej recyrkulacji spalin,

- zmiana parametrów wtrysku paliwa, zastosowanie wtryskiwaczy piezoelektrycznych,

- optymalizacja systemu doładowania silnika,

- optymalizacja układu chłodzenia silnika,

- w zakresie oczyszczania spalin:

- zainstalowanie filtrów cząstek stałych

- instalacja kombinacji reaktorów utleniających i filtrów

- zastosowanie selektywnej redukcji katalitycznej

- zamontowanie absorberów tlenków azotu

- w zakresie paliw:

- stosowanie lepszej jakości paliw (zmniejszenie zawartości siarki)

- zastępowanie paliw konwencjonalnych paliwem typu biodiesel

- stosowanie paliw alternatywnych (skroplony gaz ziemny, sprężony gaz ziemny, wodór).

Ponadto naprawiane silniki - zarówno podczas naprawy rewizyjnej i głównej - powinny być każdorazowo poddawane badaniom (np. na oporniku) w zakresie emisji składników toksycznych.

Dodatkowo, z każdego przeprowadzonego badania proponuje się sporządzenie protokołu $\mathrm{z}$ ocena, który powinien być podstawą dla uzyskania przez pojazd świadectwa sprawności technicznej i dopuszczenia do eksploatacji na Polskich Liniach Kolejowych S.A. 
Należy również zwrócić uwage na to, że dla silników trakcji spalinowej winny obowiązywać jedne procedury przeprowadzania badań i jedne limity emisji spalin, tak jak ma to miejsce, np. w Stanach Zjednoczonych i Japonii [10].

\section{Literatura}

[1] Marciniak Z., Merkisz J., Pielecha I., Pielecha J.: Mobilne stanowisko do badań emisji składników toksycznych spalin silników spalinowych. Pojazdy Szynowe, nr 3/2002.

[2] Marciniak Z., Pielecha I.: Możliwości poprawy parametrów ekologicznych silników dla naprawianych $i$ modernizowanych lokomotyw spalinowych. Pojazdy Szynowe, nr 2/2004.

[3] Marciniak Z., Pielecha I.: Sprawozdanie z oceny silnika spalinowego lokomotywy V200 (ST44) w zakresie emisji składników toksycznych spalin. Opracowanie SB-2252. Praca IPS „,Tabor" Poznań, 2004.

[4] Marciniak Z., Pielecha I.: Sprawozdanie z badania emisji sktadników toksycznych spalin silnika 5D49 lokomotywy spalinowej BR232. Opracowanie SB-2259, Praca IPS „Tabor”. Poznań 2005.

[5] Marciniak Z., Pielecha I.: Sprawozdanie z badania emisji składników toksycznych spalin silnika lokomotywy spalinowej EM62-001. Opracowanie SB-2278, Praca IPS „Tabor”. Poznań 2005.

[6] Marciniak Z., Pielecha I.: Sprawozdanie z badania emisji składników toksycznych spalin silnika lokomotywy spalinowej M62-0161. Opracowanie SB-2284, Praca IPS „Tabor”. Poznań 2006.

[7] Marciniak Z., Pielecha I.: Sprawozdanie z badania emisji sktadników toksycznych spalin silników $5 D 49$ i CAT3606 lokomotyw spalinowych BR231/BR232. Opracowanie SB-2285, Praca IPS ,,Tabor”. Poznań 2006.

[8] Pielecha I., Czerwiński J.: Sprawozdanie z badania emisji sktadników toksycznych spalin silnika lokomotywy spalinowej V200 (ST44M62) $n r$ 1241. Opracowanie SB-2275. Praca IPS , Tabor”. Poznań 2005.
[9] Pielecha I., Czerwiński J.: Sprawozdanie z badania emisji składników toksycznych spalin silnika lokomotywy spalinowej SM42 nr 2508. Opracowanie SB-2277, Praca IPS „Tabor”. Poznań 2006.

[10] Pielecha I., Pielecha J.: Tendencje $w$ przepisach dotyczacych emisji zwiazków toksycznych przez silniki spalinowe pojazdów szynowych. Pojazdy Szynowe, nr 1/2005.

[11] Raczyński J.: Ograniczanie emisji spalin $z$ silników kolejowych $w$ prawie unijnym. Technika Transportu Szynowego 2004, nr 7/8.

[12] Karta UIC 624 Badanie emisji gazów wydechowych silników spalinowych trakcyjnych. Wyd. 2 z kwietnia 2003.

[13] Directive 97/68/EC of the European Parliament and of the council z 16.12.1997, wydanie 27.02.1998.

[14] Directive 2004/26/EC of the European Parliament and of the council z 21.04.2004.

[15] Raport ORE B13 Rp. 22, Dopuszczenie do eksploatacji oraz utrzymywanie silników spalinowych. Graniczne wartości emisji składników toksycznych spalin silników spalinowych. Utrecht, kwiecień $1978 \mathrm{r}$.

[16] Norma PN-EN ISO 8178-1, Silniki spalinowe tlokowe. Pomiar emisji spalin. Pomiar emisji sktadników gazowych i czastek statych na stanowisku badawczym. Wyd. styczeń 1999.

[17] Norma PN-EN ISO 8178-4, Silniki spalinowe tłokowe. Pomiar emisji spalin. Cykle badawcze silników o różnym zastosowaniu. Wyd. styczeń 1999.

[18] Karta UIC 623-2, Badania homologacyjne silników spalinowych pojazdów napędowych. Wyd. 3 z kwietnia 2005.

[19] Marciniak Z., Pielecha I.: Próby i badania silników spalinowych lokomotyw i lekkich pojazdów szynowych $w$ aspekcie poprawy ich parametrów eksploatacyjnych. XVIII Konferencja Naukowa „Pojazdy Szynowe”, Katowice-Ustroń, 17-19 września 2008. 